\title{
A REVIEW OF EMERGING GHG EMISSIONS TRADING IN NORTH AMERICA: Fragmentation OR PROGRESS?
}

\author{
GRANT BOYLE*
}

A patchwork of greenhouse gas (GHG) emissions trading regulations has emerged in North America, with regulations emerging at provincial, federal, state, interstate, and international levels. This patchwork of systems differs from the earlier approach taken by other jurisdictions, such as in the European Union. The author reviews the North American schemes, detailing their key features, drawing comparisons between the systems, and discussing the implications for the future of GHG emissions trading in the United States and Canada. The author argues that while there is likely to be some degree of convergence, the regional and political diversity that underpins the patchwork approach will continue to influence the design of any larger trading system, including efforts to establish a global emissions trading system.
Une mosaïque de règlements commerciaux sur les émissions de gaz à effet de serre est apparue en Amérique du Nord, avec des règlements émergeant au niveau provincial, fédéral, étatique, interétatique et international. Cette mosaïque de systèmes diffère des approches antérieures adoptées par d'autres ressorts, notamment l'Union européenne. L'auteur revoit les plans nord-américains, donnant le détail de leurs caractéristiques principales, comparant les systèmes et examinant les implications de l'avenir du commerce des émissions de gaz à effet de serre aux États-Unis et au Canada. L'auteur prétend qu'alors qu'il y a une certaine convergence, la diversité régionale et politique sous-jacente à cette mosaïque continuera d'influencer le modèle d'un système commercial plus grand, incluant l'effort d'établir un système mondial de commerce d'émissions.

\section{TABLE OF CONTENTS}

I. INTRODUCTION . . . . . . . . . . . . . . . . . . . . . . . . . . . . . . . 174

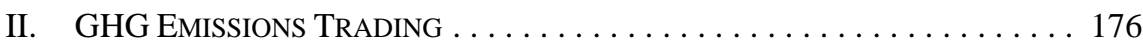

A. Compliance EMisSions TRAding $\ldots \ldots \ldots \ldots \ldots \ldots \ldots \ldots \ldots$

B. Project Offset Trading $\ldots \ldots \ldots \ldots \ldots \ldots \ldots \ldots \ldots . \ldots \ldots$

III. GHG EMISSIONS TRAding IN THE United StATES $\ldots \ldots \ldots \ldots \ldots \ldots$

A. LIEBERMAN-WARNER BILl . . . . . . . . . . . . . . . . 180

B. Northeast States Regional GreENHOUSE Gas

Initiative (RGGI) . . . . . . . . . . . . . . . . . . . . . . 183

C. Western Climate Initiative . . . . . . . . . . . . . . . . . . 185

D. MidWESTERn REgIONAL GREENHOUSE GAS

REDUCTION ACCORD . . . . . . . . . . . . . . . . . . . 187

IV. GHG EMISSIONS TRADING IN CANADA $\ldots \ldots \ldots \ldots \ldots \ldots \ldots \ldots$

A. FEDERAl REgulatory FrameWork ON Air EMISSIONS ...... 188

B. AlBerta's SPECIFIEd Gas EMitTers RegUlation . . . . . . . . 190

V. Comparing Scope, Allocations, AND Project OfFSETS $\ldots \ldots \ldots 192$

VI. IMPLICATIONS AND DISCUSSION $\ldots \ldots \ldots \ldots \ldots \ldots \ldots \ldots \ldots \ldots \ldots \ldots$

A. FRAGMENTATION BEFORE CONVERGENCE

in NORTH AMERICA? . . . . . . . . . . . . . . . . . . . . . . . . . . . . . . . 194

2009 LL.B. Candidate, Osgoode Hall Law School. The author previously worked as a law student at Davis LLP in Vancouver and prior to studying law, worked for several years as an energy and environmental policy researcher at the United Nations University in Tokyo. The author would like to thank Professors Dayna Scott and Stepan Wood of Osgoode Hall Law School for their comments on earlier drafts of this article. 


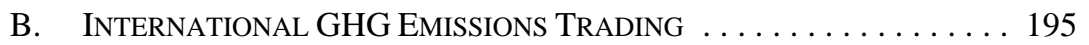

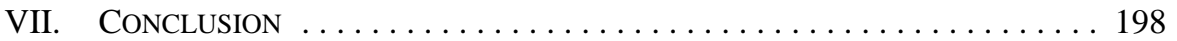

VIII. APPENDiX A: PROPOSED EMissions AllowANCES AllocAtion . . . . . 200

\section{INTRODUCTION}

The United States and Canada are in the process of developing new regulations to curb greenhouse gas (GHGs) emissions. As in many industrialized countries around the world, emissions trading has emerged as the regulatory instrument of choice among state, provincial, and federal actors in North America. Alberta has implemented a GHG emissions trading scheme, several northeastern American states will start an interstate scheme in January 2009, and several Midwestern states, several western states and British Columbia, Quebec, Manitoba, and Ontario are designing a co-operative cap-and-trade scheme. Both federal governments are also in the process of developing regulations and legislation for national emissions trading schemes.

This patchwork and regional approach to GHG emissions trading is different from the approach taken in earlier efforts in other jurisdictions and contexts. The European Union Emissions Trading System (EU-ETS), launched in 2005 to cover 12,000 facilities in (now) 27 countries was undertaken by European Union (EU) countries with significant central guidance from the European Commission. The Kyoto Protocol to the United Nations Framework Convention on Climate Change, ${ }^{1}$ which came into force in 2005, includes a country-to-country emissions trading system for 38 countries and was designed by the Conference to the Parties of the Kyoto Protocol. The system creates inter-country trading (art. 17) as well as inter-country offset trading (Joint Implementation/art. 6) and offset trading with uncapped developing countries party to the Protocol (Clean Development Mechanism/art. 12). The patchwork approach observable in North America also diverges from the vision of a global carbon market that underpins many approaches to current international negotiations for a post-2012 agreement under the United Nations Framework Convention on Climate Change (UNFCCC). ${ }^{2}$

Although the U.S. is party to the UNFCCC and encouraged the adoption of emissions trading under the Kyoto Protocol and Canada has also ratified the Kyoto Protocol, neither country is making a serious attempt to engage these emissions trading mechanisms. Instead, Canada and the U.S. are focused on their own domestic trading systems, led largely by provinces, states, and other entities. This article reviews emerging North American GHG emissions trading systems with a view to characterizing and comparing the efforts underway in different jurisdictions - state, provincial, regional, and federal. How do the different systems compare to one another and where is GHG emissions trading headed in North America? Is North America lagging behind on integration or is the fragmented, patchwork approach to GHG emissions trading the new way of the future?

11 December 1997, UN Doc. FCCC/CP/1997/7/Add.1, 37 I.L.M. 22 (entered into force 16 February 2005), online: United Nations Framework Convention on Climate Change (UNFCCC) <http://www. unfccc.int/resource/docs/convkp/kpeng.pdf> [Kyoto Protocol].

2 World Business Council for Sustainable Development (WBCSD), Establishing a Global Carbon Market: A discussion on linking various approaches to create a global market (4 December 2007), online: WBCSD <http://www.wbcsd.org/DocRoot/wrHqIUtkoNq4sC2wodX8/linkages.pdf>. 
While the policy context is changing quickly, the analysis shows that although there is likely to be some degree of convergence in emissions trading systems in the U.S. and Canada, the GHG emissions trading systems that are emerging are significantly diverse as measured by design features concerning scope, allocations, and use of offsets. ${ }^{3}$ This article details some of the key features of the different schemes under development, draws comparisons between the systems, and discusses the implications for the future of GHG emissions trading in North America and the implications for international GHG emissions trading. The article argues that the regional and political diversity that underpins the patchwork approach observable in North America is indicative of the diversity that is likely to inform other approaches to emissions trading around the world, including post-Kyoto Protocol discussions and wider use of international or regional emissions trading outside of the EU.

Part II of the article develops a framework for understanding and comparing different types of emissions trading systems and different design features in emissions trading. The section describes a framework for comparison based on three main features of emissions trading: (1) the scope of the coverage and reduction targets of the system; (2) the method for allocating pollution allowances; and (3) the scope and nature of project offsets that are allowed in the system. Part III reviews emerging emissions trading systems in the U.S. and Part IV reviews emerging systems in Canada. Part V highlights and compares the systems that are reviewed and Part VI considers the implications of these trends for international emissions trading as well as international climate change co-operation in general.

The article does not consider voluntary emissions trading systems. Although voluntary GHG emissions trading has seen rapid growth in North America that will likely continue, the article looks primarily at the emerging government regulations that will lead to the deep reductions that are required by the middle of the century. ${ }^{4}$ In addition, voluntary approaches to GHG emissions reductions have been used in the U.S. and Canada for several years without success ${ }^{5}$ and many volunteer emissions trading initiatives are developing in anticipation of the regulations that are now beginning to unfold. ${ }^{6}$

The article does not consider how emissions trading fits into a wider mix of government efforts related to carbon taxes, research and development, and more traditional regulation like efficiency standards. The article does presume, however, that the government is required, either through a tax, a cap-and-trade system, or regulation, to impose a long-term price signal on carbon emissions in order to provide lasting certainty regarding the cost of emissions and

These design features will be explained below.

Bert Metz et al., Climate Change 2007: Mitigation of Climate Change: Contribution of Working Group III to the Fourth Assessment Report of the Intergovernmental Panel on Climate Change (Cambridge, U.K.: Cambridge University Press, 2007).

5 See Mark Jaccard et al., "Burning Our Money to Warm the Planet: Canada’s Ineffective Efforts to Reduce Greenhouse Gas Emissions” (2006) 234 C.D. Howe Institute Commentary, online: C.D. Howe Institute <http://www.cdhowe.org/pdf/Commentary_234.pdf>; Cass R. Sunstein, "Of Montreal and Kyoto: A Tale of Two Protocols” (2007) 31 Harv. Envtl. L. Rev. 1.

$6 \quad$ Jeremy Weinstein, "Carbon Trading Markets and the Verified Emissions Reduction Purchase and Sale Agreement (VERPA)" (Renewable Energy Teleconference Series: American Council on Renewable Energy, 20 February 2008), online: American Council on Renewable Energy <http://www.acore.org/ renewableenergyinfo/includes/resource-files/main\%20presentation_web.pdf $>$. 
to bring new technologies to market. ${ }^{7}$ Such a market forcing device is required even if governments begin investing heavily in research and development.

Nor does the article attempt to assess the environmental effectiveness, economic efficiency, administrative ease, or political feasibility of the different emissions trading systems under review or consider all the important design features of emissions trading schemes. For example, the article does not look at "credit for early action” or "leakage provisions" in the different schemes. Nonetheless, the article does look to scope, allocations, and offsets as proxies for a meaningful comparison - particularly in terms of environmental stringency. ${ }^{8}$ Finally, the article only considers the status of emissions trading in the U.S. and Canada at the time of writing. It does not consider any efforts underway in Mexico and concedes that many of the details reported below are likely to change in coming months as policy develops and new initiatives come online.

\section{GHG EMISSIONS TRADING}

Emissions trading systems, like all forms of environmental regulation, define different rights and duties among different actors with regard to the management of natural resources. ${ }^{9}$ At their core, most air pollution emissions trading systems establish a state's duty to manage pollution levels, a private actor's right to emit a certain amount of pollution over time, and a private actor's right to trade emission rights. The latter right to trade essentially gives emissions trading its "market-based" status, distinguishable from other "regulatory" or "command and control" approaches. In theory, this additional trading right allows firms with the lowest abatement costs to undertake most of the abatement in the short term, at lower overall costs to society. ${ }^{10}$

Notwithstanding the popular description of emissions trading as a market-based instrument and the proliferation of markets for voluntary offset credits, the emissions trading schemes discussed below are state-centred, regulatory projects. The central role of the state in emissions trading can be traced to its conceptual origins. J.H. Dales, ${ }^{11}$ who is often credited with originating the instrument, sees pollution trading as a cost-effective way to reach an emissions target set by the state. Where market forces would be enlisted to encourage an efficient re-allocation of rights, the creation of pollution rights would be left to the state. In this sense, the characterization of emissions trading as a "market-based" approach as opposed to a "command and control” one may not be very helpful. ${ }^{12}$

Nicholas Stern, The Economics of Climate Change: The Stern Review (Cambridge, U.K. Cambridge University Press, 2007).

For a discussion on emissions trading and environmental stringency, see David Driesen, "Economic Instruments for Sustainable Development” in Benjamin J. Richardson \& Stepan Wood, eds., Environmental Law for Sustainability: A Reader (Oxford: Hart, 2006) 277.

Daniel H. Cole, Pollution and Property: Comparing Ownership Institutions for Environmental Protection (Cambridge, U.K.: Cambridge University Press, 2002).

Tom Tietenberg et al., International Rules for Greenhouse Gas Emissions Trading: Defining the principles, modalities, rules and guidelines for verification, reporting and accountability (Geneva: UN, 1999) (UN Doc. UNCTAD/GDS/GFSB/Misc.6), online: United Nations Conference on Trade and Development <http://www.unctad/org/en/docs/pogdsgfsbmb.en.pdf>.

J.H. Dales, Pollution, property \& prices: An essay in policy-making and economics (Toronto: University of Toronto Press, 1968).

Supra note 8 at 283. 


\section{A. Compliance Emissions Trading}

\section{CAP-AND-TRADE}

In a cap-and-trade system, a regulator establishes an aggregate emissions cap for a group of polluters and allocates permits, which include the right to emit a specific amount of pollution over a time period. Polluters can trade allowances among themselves based on market prices. The EU-ETS established an absolute cap on carbon dioxide $\left(\mathrm{CO}_{2}\right)$ emissions for about 12,000 large industrial facilities in the power sector and other industrial units and combustion facilities - about half of all sources of $\mathrm{CO}_{2}$ in the EU. The cap in the EU-ETS was the sum of separate caps in participating states, subject to the review of the European Commission. ${ }^{13}$

While GHG cap-and-trade systems are relatively new, the U.S. has been using such schemes to control other pollutants for several years. The Acid Rain Program, where the federal government placed an aggregate cap on sulfur dioxide $\left(\mathrm{SO}_{2}\right)$ emissions from the 263 highest-emitting factories in the country during the 1990s is often cited as a successful capand-trade program. ${ }^{14}$ According to estimates, the emissions reduction targets were achieved at a cost that was 20 percent lower than it would have been without trading. ${ }^{15}$ According to David Driesen, the success of the program was backed by continuous emissions monitoring, a cap on the mass of emissions, and clear, game-proof rules. ${ }^{16}$

\section{BASELINE AND CREDIT}

In a baseline and credit compliance system, a regulator establishes a baseline level of emissions for each polluter in a regulated group and emitters that reduce emissions beyond the baseline can earn credits which can be traded at market prices among other emitters. Unlike a cap-and-trade system, which issues allowances in aggregate at the outset of the program, a baseline and credit system involves trade in credits that are created when a firm demonstrates performance beyond the designated baseline.

According to Tom Tietenberg et al., the U.S.-led phase out program of 1982 was a baseline and credit system that achieved moderate success. In that program, oil refiners that reduced the lead content of gasoline beyond required reductions could earn credits, which could be traded with other refiners. ${ }^{17}$ There was significant trading, particularly among small

13 A. Denny Ellerman \& Paul L. Joskow, The European Union's Emissions Trading System in perspective (Arlington, Va.: Pew Center on Global Climate Change, 2008).

14 See e.g. Mark Jaccard, Sustainable Fossil Fuels: The Unusual Suspect in the Quest for Clean and Enduring Energy (New York: Cambridge University Press, 2005) at 283; Stewart A.G. Elgie, "Carbon Offset Trading: A Leaky Sieve or Smart Step?” (2007) 17 J. Envtl. L. \& Prac. 235 at 246.

Ibid.

Supra note 8 at 298.

The United States Environmental Protection Agency (EPA) set a limit of an average level of $1.1 \mathrm{gm} / \mathrm{gal}$ beginning on 1 November 1982. The EPA lowered the average to $0.5 \mathrm{gm} / \mathrm{gal}$ by 1 July 1985, and then to $0.1 \mathrm{gm} / \mathrm{gal}$ by 1 January 1986 . The EPA allowed two forms of trading: inter-refinery averaging during each quarter and banking for future use or sale. See U.S. Environmental Protection Agency, “6.6 Lead Credit Trading,” online: U.S. EPA <http://yosemite.epa.gov/ee/epalib/incent2.nsf/384624008775 ddb88525634e003fdb8b/a55491f5c7581e2f85256ab2007043b9!OpenDocument>. 
refiners who faced significantly higher marginal costs of control than larger refiners, and overall costs of compliance were considered to be lower than they would have been without trading. At the same time, the program experienced a significant number of reporting violations, which ultimately led regulators to establish stricter standards for credit creation and trading in future programs, which in turn, ultimately inhibited trading in those programs. $^{18}$

While most GHG emissions trading systems under development are cap-and-trade systems, some are baseline and credit systems including the New South Wales Greenhouse Gas Reduction Scheme ${ }^{19}$ and the Alberta Specified Gas Emitters Regulation ${ }^{20}$ discussed below.

\section{ALLOCATIONS}

In a cap-and-trade system, emission rights are allocated by the state, typically based on historic emissions. Grandfathering rights in this way, recognizes emission rights that already exist at the outset of regulation, but may exacerbate problems associated with regulatory capture. $^{21}$ If allowances are distributed at no cost, firms will have incentives to distort emission projections so as to create windfalls, which is what appears to have occurred in the first phase of the EU-ETS. ${ }^{22}$ At the same time, this over-allocation appears less likely in the second phase, given the new availability of verified emissions data and more ambitious targets. ${ }^{23}$ Giving away allowances can also entice firms to carry on with an unprofitable business when they would have otherwise exited the industry and can prevent new businesses from entering a sector if they are not able to obtain permits. One solution here is to divide an emissions program into phases so that the rights are only valuable for a limited period. ${ }^{24}$ Also, new entrants can be granted short-term exemptions or reserves can be set-aside for new entrants.

Another solution is to auction all or a portion of the allowances. If auctions are competitive, polluting enterprises will calculate their abatement costs more accurately and will not have the same incentive to manipulate allocations. In addition, auctioning allowances helps to encourage the "polluter pays" principle. One problem with auctions is that smaller firms, such as small power plant operators, may have difficulty bidding against larger, more established firms, and so giving away some allowances may be appropriate. The EU-ETS, as well as the North American systems discussed below, are beginning to auction an increasing portion of allowances and contemplating the use of auction proceeds to fund technology development. Proposed allocation plans for the second phase of the EU-ETS

18 Supra note 11.

19 Online: Greenhouse Gas Reduction Scheme <http://www.greenhousegas.nsw.gov.au/>.

$20 \quad$ Alta. Reg. 139/2007 [Emitters Regulation].

$21 \quad$ Supra note 14 at 283.

22 U.K., H.C. Environmental Audit Committee, "The EU Emissions Trading Scheme: Lessons for the Future: Second Report of Session 2006-07,” HC 70 in Sessional Papers (2006-07), online: United Kingdom Parliament <http://www.publications.parliament.uk/pa/cm200607/cmselect/cmenvaud/70/ 70.pdf>.

$23 \quad$ Supra note 13 at 31 .

$24 \quad$ Jonathan Remy Nash, "Too Much Market? Conflict Between Tradable Pollution Allowances and the 'Polluter Pays’ Principle” (2000) 24 Harv. Envtl. L. Rev. 465. 
indicate, for example, that 8.8 percent of allowances will be auctioned in Germany and 7 percent in the United Kingdom, while proposed amendments to the EU Emissions Trading Directive would establish a principle of 100 percent auctions.

\section{B. Project Offset Trading}

In compliance emissions trading, governments may also allow emitters to acquire emission rights by partaking in the development of a project or by contracting with a project developer who undertakes an activity to reduce emissions against "business as usual" activities. Offset projects are undertaken on a voluntary basis, and the emission rights can be sold from their project to a voluntary buyer ${ }^{25}$ or to a buyer who has emissions reduction obligations under one of the compliance schemes discussed above.

The most developed GHG offset system is the Clean Development Mechanism (CDM) ${ }^{26}$ of the Kyoto Protocol, which has been in operation for several years, driven primarily by demands from the EU-ETS, through the EU Linking Directive and some other developed country parties to the Kyoto Protocol. ${ }^{27}$

Offset trading is significantly different from the compliance trading schemes discussed above in that each project is developed and approved on a case-by-case basis. A project proponent must establish a baseline for future emissions, develop and monitor the emissions reducing activity of the project, and have the results verified by a third party. According to Stewart A.G. Elgie, rigorous baseline studies can be undertaken to ensure that a project actually reduces emissions, but such studies are expensive and increases the transaction costs of projects. ${ }^{28}$ Sophisticated methods include looking at a firm's business forecast, industry trends, and third party analyses of expected activities. There can also be an economic viability analysis, which considers whether the proposed project makes economic sense without the credit payments. Developers may also be required to show how their project addresses "leakage," which occurs when emission reductions at one site leads to increased

25 Voluntary demand for offset is believed to stem from entities who are anticipating future legal obligations, undertaking voluntary compliance, improving public relations, developing market expertise, and responding to increasing pressure from stock analysts, investment institutions, insurance companies, and to the threat of climate litigation. See Martijn Wilder, Monique Willis \& Mina Guli, "Carbon Contracts, Structuring Transactions: Practical Experiences” in David Freestone \& Charlotte Streck, eds., Legal Aspects of Implementing the Kyoto Protocol Mechanisms: Making Kyoto Work (Oxford: Oxford University Press, 2005) 295.

$26 \quad$ Supra note 1 , art. 12.

27 As of November 2008, the CDM Executive Board had issued 204 million certified emission reductions (CERs) (1 CER equals 1 ton $\mathrm{CO}_{2}$ equivalent) and registered 1190 projects, online: UNEPRIS Centre <http://www.cdmpipeline.org/overview.htm>. See United Nations Environmental Programme (UNEP), online: UNEP < http://www.unep.org>. In 2006, US\$ 5 billion/(450 $\mathrm{MT} \mathrm{CO}_{2}$ equivalent) were transacted through the CDM. Thirty-four percent came from hydrofluorocarbon (HFC) destruction projects, 13 percent from nitrous oxide $\left(\mathrm{N}_{2} \mathrm{O}\right)$ destruction projects, 6 percent from hydroelectricity, 3 percent from wind, 2 percent from other renewables, 9 percent from energy efficiency and fuel switching, 1 percent from agro-forestry, 7 percent from coal mine methane, 5 percent from landfill gas, 2 percent from animal waste, and 13 from percent other. See Karan Capoor \& Philippe Ambrosi, State and Trends of the Carbon Market 2006 (Washington: World Bank, 2006), online: The World Bank Carbon Finance Unit $<$ http://carbonfinance.org/docs/StateoftheCarbonMarket2006.pdf>. 
emissions growth at another. ${ }^{29}$ The consequence of these required proofs is that the costs of ensuring environmental integrity of offset projects can be high; possibly high enough to erode the cost savings associated with emissions trading to start with. However, where an offset system establishes less onerous proofs, there is less reliability the emissions reductions are real. ${ }^{30}$

So-called "sink" projects that sequester carbon in forestry and soil through afforestation, reforestation, or tillage techniques add another layer of complexity. The natural degeneration of forests or unforeseen events could compromise emissions reductions from such projects (for example, forest fires) and so proponents are faced with "permanence” risk. As a result, such projects may be issued temporary credits or discounted credits. ${ }^{31}$ Sink projects are further complicated by risks that such projects take place on land, where existing fee simple or timber rights could compromise the integrity or longevity of the emission rights on that land. ${ }^{32}$

Notwithstanding the challenges, offset trading has support in many emerging GHG programs as a cost mitigation tool or price "safety valve" and as a way to direct subsidies from capped emitters to actors outside the cap. At the same time, policy-makers are increasingly implementing rules that limit the number of offsets that can be used and structuring the types of projects that are acceptable for compliance, apparently in recognition of the primary desire to reduce emissions among the capped group.

\section{GHG EMISSIONS TRADING IN THE UNITED STATES}

\section{A. LIEBERMAN-WARNER BILL}

Recent activity in the Congress and Senate has produced a number of bills that could be passed under a new American administration in coming years. Bill 2191,33 also known as the Lieberman-Warner Bill or the Climate Security Act, emerged as one of the leading pieces of federal draft legislation, which, while defeated in June 2008 in the U.S. Senate, was the first cap-and-trade bill to leave committee in the U.S. Congress. The proposed system would create an economy-wide cap-and-trade program in the U.S., administered by the Environmental Protection Agency.

According to A Summary of the Core of the Bill posted by the Senate, the purposes of the CSA are:

For example, a reforestation project may simply displace a given agricultural or logging activity if the demand for the emitting activity curtailed by the project can be captured by new or additional supply that can be brought online, outside the "boundary" of the project.

Elgie, supra note14 at 254.

Under the Kyoto Protocol, supra note 1, Annex 1 countries are allowed to use forestry offsets for only 1 percent of reduction obligations and the EU-ETS does not allow credits from CDM forestry projects. Steven A. Kennett, Arlene J. Kwasniak \& Alastair R. Lucas, "Property Rights and the Legal Framework for Carbon Sequestration on Agricultural Land" (2005) 37 Ottawa L. Rev. 171.

33 U.S., Bill S. 2191, Lieberman-Warner Climate Security Act of 2007, 110th Cong., 2007, online: Joe Lieberman <http://lieberman.senate.gov/documents/lwcsa.pdf $>$ [CSA]. 
(1) to establish the core of a federal program that will reduce United States greenhouse gas emissions substantially enough between 2007 and 2050 to avert the catastrophic impacts of global climate change; and

(2) to accomplish that purpose while preserving robust growth in the United States economy, creating new jobs, and avoiding the imposition of hardship on United States citizens. ${ }^{34}$

\section{SCOPE AND TARGETS}

The proposed cap-and-trade program is economy-wide and includes 86 percent of GHG emissions in the U.S. covered facilities include coal-burning power plants and industries, natural-gas processing plants and importers, petroleum- or coal-based fuel producers and importers, and facilities that produce or import (for sale) GHG such as sulfur hexafluoride or perfluorocarbons. ${ }^{35}$ The Bill designates $\mathrm{CO}_{2}$, methane, $\mathrm{N}_{2} \mathrm{O}$, sulfur hexafluoride, and perfluorocarbons - as “Group 1 greenhouse gases,” and HFCs as “Group 2 greenhouse gases,” which are dealt with separately and have separate trading markets and declining caps. The draft bill requires covered sources to reduce emissions from 2005 levels by 4 percent by 2012, 19 percent by 2020, and 71 percent by 2050 .

\section{ALLOCATIONS ${ }^{36}$}

Title 1, Subtitle B, Section 1201 directs the U.S. EPA to establish an emission allowance account for each calendar year from 2012 through 2050. ${ }^{37}$ The EPA would give away a portion of the allowances to capped emitters at the outset of the program and auction a proportion (that increases over time) through an entity called the Climate Change Credit Corporation. ${ }^{38}$ Under Title 2, capped facilities have the right to bank allowances for an indefinite period ${ }^{39}$ and can borrow allowances from future years at a 10 percent interest rate. ${ }^{40}$ By 2012, the EPA would auction 21.5 percent of the total allowances and this proportion would rise steadily each year and then plateau at 69.5 percent from 2031 through 2050 . In effect, however, the CSA contemplates a 100 percent auction among capped emitters by 2031

The Lieberman-Warner Climate Security Act (s. 2191): A Summary of the Core of the Bill (as reported from the Senate Environment and Public Works Committee on 5 December 2007), online: Joe Lieberman <http://lieberman.senate.gov/documents/detailedacsa.pdf >, citing ibid., s. 3.

Capped entities include: any facility that uses more than 5,000 tons of coal in a year; any facility that is a natural gas processing plant or produces natural gas in the State of Alaska, or any entity that imports natural gas (including liquefied natural gas); any facility that in any year produces, or any entity that in any year imports, petroleum- or coal-based liquid or gaseous fuel, the combustion of which will emit GHG, assuming no capture and sequestration of that gas; any facility that in any year produces for sale or distribution, or any entity that in any year imports, more than $10,000 \mathrm{CO}_{2}$ equivalents of GHG, assuming no capture and destruction or sequestration of that gas; and any facility that in any year emits as a by-product of the production of HFCs more than $10,000 \mathrm{CO}_{2}$ equivalents of HFCs.

For a complete breakdown of the proposed allocations method, see Appendix A. Note the allocation method has changed with several revisions of the Bill.

The size of the 2012 account will equal GHG emissions in 2005 or 5.775 billion allowances. The number of allowances in any given year account will be 106 million fewer than the number in the immediately preceding year account (106 million is 1.8 percent of 5.775 billion). The size of the 2050 account is 1.732 billion allowances or an amount 70 percent below 2005 emissions. Supra note 33. Ibid., Title IV, Subtitle B. The Climate Change Credit Corporation would have a board of directors composed of five individuals appointed by the President, with the advice and consent of the Senate, for staggered five-year terms.

Ibid., s. 2202.

Ibid., s. 2302. 
since the remaining allowances given away freely are actually "set-asides" 41 or subsidies directed at particular entities or activities. ${ }^{42}$

In addition, the CSA specifies how proceeds from auctions will be allocated. For all years of the program, 52 percent of auction proceeds will go to technology deployment, 18 percent to low-income consumers, 18 percent to wildlife adaptation, 5 percent to international adaptation, 5 percent to worker training, and 2 percent to advanced energy research.

\section{PROJECT OFFSETS}

Title 2, Subtitle D of the CSA directs the EPA, with the Secretary of Agriculture, to promulgate regulations allowing covered facilities to satisfy up to 15 percent of a given year's compliance obligation with offset allowances generated within the U.S. starting in 2012. ${ }^{43}$ The CSA also directs the EPA to promulgate regulations allowing a covered facility to satisfy up to 15 percent of a given year compliance obligation with "international emission allowances” from approved emissions trading markets. In developing the regulations, the EPA is to take into consideration "protocols adopted in accordance with the United Nations Framework Convention on Climate Change." ${ }^{44}$ In addition, the Bill says that the regulations shall require that in order to be approved, an international emissions allowance shall have been issued by a foreign country pursuant to a governmental program that imposes mandatory absolute tonnage limits on GHG emissions in that foreign country or one or more industry sectors in that country and that the governmental program be of comparable stringency to the program established by the CSA, including comparable monitoring, compliance, and enforcement. ${ }^{45}$

Before allowances are issued to a project developer, the project developer must submit a "petition" to the EPA which contains at least a copy of the monitoring and quantification plan for the project and an "initiation certification," indicating a pre-registration requirement for projects. The Bill directs the EPA and the Secretary of Agriculture to develop standardized methods for use in accounting for additionality, uncertainty (permanence), baselines, and discounting for leakage for each project type. ${ }^{46}$

The CSA also gives the EPA power to adjust the number of allowances awarded to a project where there is a determination of "significant deviation" (based on standards that the EPA develops) "as a result of activities or behavior inconsistent with the purposes of [the] title. ${ }^{47}$ Under the draft bill, the EPA has the power to declare a project invalid if it sustains

\section{Supra note 36.}

Set-asides are planned for: state governments (10.5 percent); electricity consumers as rebates to lowincome consumers and to promote consumer energy efficiency ( 9 percent); farmers and foresters who undertake carbon sequestration activity (5 percent); international forest protection to reduce tropical deforestation (2.5 percent); natural gas consumers as rebates to low-income consumers and to promote consumer energy efficiency ( 2 percent); methane reduction projects (1 percent); and tribal governments (0.5 percent). Ibid.

Supra note 33, s. 2402.

Ibid., ss. 2501, 2502(a).

Ibid., s. 2502(b).

Ibid., s. 2404.

Ibid., s. 2404(e)(3)(B). 
a complete reversal or to require adjustments of projects that sustain a partial reversal. The Bill also places liability for a project reversal on the "owner of the offset allowance"48 and directs the EPA to develop regulations that would permit the EPA to reject projects where the implementation of the project would have adverse environmental or health impacts. ${ }^{49}$

\section{B. NORTHEAST STATES REgIONAL GREENHOUSE GAS INITIATIVE (RGGI)}

In December 2005, Connecticut, Delaware, Maine, New Hampshire, New Jersey, New York, and Vermont (Signatory States) agreed in a Memorandum of Understanding ${ }^{50}$ to implement a cap-and-trade system for $\mathrm{CO}_{2}$ emissions from electric utilities in the region, described as a " $\mathrm{CO}_{2}$ Budget Trading Program." ${ }^{51}$ Maryland has subsequently joined and the District of Columbia, Massachusetts, Pennsylvania, Rhode Island, and New Brunswick are observers in the process. The cap-and-trade system of these northeastern states — known as the RGGI — will be the first regulatory emissions trading system for GHGs in the U.S. and is due to begin in January 2009. In 2006, participating states issued the Regional Greenhouse Gas Initiative Model Rule $e^{52}$ based on an EPA guidance rule provided to states in the implementation of previous federal trading programs for nitrogen oxide and $\mathrm{SO}_{2}$. Participants are expected to finalize regulations by the end of 2008 .

The $M O U$ acknowledges that the Signatory States "each individually have a policy to conserve, improve, and protect their natural resources and environment,"53 but "find it imperative to act together to control emissions of greenhouse gases, particularly carbon dioxide, into the Earth's atmosphere from within their region." ${ }^{44}$ The $M O U$ also recognizes the desire of the Signatory States to "establish themselves and their industries as world leaders" in technology. ${ }^{55}$ Concerning the potential relationship between the RGGI and similar American federal regulations, the $M O U$ says that if a federal cap-and-trade program is proposed, the Signatory States will advocate for a federal program that will reward states that are first movers and further specifies that if such a federal program is adopted, and it is determined to be comparable to the RGGI, the Signatory States will transition into the federal program. $^{56}$

\section{SCOPE AND TARGETS}

The RGGI regulates $\mathrm{CO}_{2}$ emissions from fossil fuel-fired electricity generating units that have a rated capacity equal to or greater than 25 megawatts, which effectively covers 95

Ibid., s. 2406(c).

Ibid., s. 2410(a).

Regional Greenhouse Gas Initiative, Memorandum of Understanding (20 December 2005), online: RGGI <http://www.rggi.org/docs/mou_12_20_05.pdf> [RGGI, MOU].

Regional Greenhouse Gas Initiative, "Overview of RGGI $\mathrm{CO}_{2}$ Budget Trading Program" (October 2007), online: RGGI <http://rggi.org/docs/program_summary_10_07.pdf> [RGGI, “Overview”].

Regional Greenhouse Gas Initiative, Regional Greenhouse Gas Initiative Model Rule (5 January 2007), online: RGGI <http://rggi.org/docs/model_rule_corrected_1_5_07.pdf> [RGGI, Model Rules].

Supra note 50 at 1.

Ibid. at 2.

Ibid. at 1.

Ibid. at 10. 
percent of $\mathrm{CO}_{2}$ emissions from the electric generation sector in the region. The $M O U$ calls for the Signatory States to stabilize power sector $\mathrm{CO}_{2}$ emissions over the first six years of the program at current emission levels, ${ }^{57}$ before reducing emissions 2.5 percent per year for the four years from 2015 to $2018 .^{58}$ This approach will result in a 2018 annual emissions cap at 10 percent below current levels.

\section{AlLOCATIONS}

The $\mathrm{MOU}$ apportions $\mathrm{CO}_{2}$ allowances among the Signatory States based on historical emissions and through negotiation. Larger states such as New York, New Jersey, and Connecticut have larger allocations. The states, in turn are free to allocate allowances among power generation facilities as “determined appropriate by each Signatory State, provided: ... each Signatory State [allocate 25 percent of the allowances to] consumer benefit or strategic energy purpose." ${ }^{59}$ Most states will auction the remaining 75 percent of allowances. New York, Massachusetts, Vermont, Rhode Island, Connecticut, and Maine have publicly stated their intent to auction all or nearly all of their allowances, and Connecticut, Rhode Island, Vermont, and Maine have statutory requirements to this effect. ${ }^{60}$ Under the RGGI, Model Rule, allowances can be traded and banked by capped emitters. The program has three compliance periods, three years each, starting in January 2009, and at the end of each compliance period a regulated facility must have enough allowances in its account.

\section{PROJECT OFFSETS}

The MOU and the RGGI, Model Rule allow sources in the RGGI to satisfy only 3.3 percent of a unit total compliance obligation during a compliance period. This option expands to 5 percent and 10 percent if the market price for allowances remain at US\$7 and $\$ 10$ respectively for a 12-month period. Eligible offset projects may be located in any participating state, any other state, or any American jurisdiction in which a co-operating regulatory agency has entered into an agreement with the participating states to provide oversight support related to $\mathrm{CO}_{2}$ emissions offset projects in that state or American jurisdiction. ${ }^{61}$ If the 12 -month rolling average $\mathrm{CO}_{2}$ allowance price hits $\$ 10$, the jurisdictional scope of eligible offset credits expands to include offsets under "any mandatory carbon constraining program outside the United States that places a specific tonnage limit on greenhouse gas emissions, or greenhouse gas emissions reduction credits certified pursuant to the [UNFCCC] or protocols adopted through the UNFCCC process." ${ }^{2}$

Supra note 51 at 2 . The initial regional cap is approximately 4 percent above annual average regional emissions during the period 2000-2004.

The regional annual $\mathrm{CO}_{2}$ emissions cap (in short tons) is: 2009-2014: 188,076,976 tons; 2015 : 183,375,052 tons; 2016: 178,673,127 tons; 2017: 173,971,203 tons; and 2018: 169,269,278 tons: ibid. Supra note 50 at 6: "Consumer benefit or strategic energy purposes include the use of the allowances to promote energy efficiency, to directly mitigate electricity ratepayer impacts, to promote renewable or non-carbon-emitting energy technologies, to stimulate or reward investment in the development of innovative carbon emissions abatement technologies with significant carbon reduction potential, and/or to fund administration of this Program.”

Supra note 51 at 4.

Ibid. at 9.

Ibid. at 7. 
The RGGI currently allows only five specific types of offset projects. ${ }^{63}$ The RGGI, Model Rule sets out specific guidelines for each of the five project types. Each project has a prescribed methodology for showing additionality. The performance standard - emission rates, energy efficiency criteria, and market penetration rates, for example, are based on "standard market practice" and projects that exceed the standard qualify as additional. ${ }^{64}$ Section 10(5) outlines specific calculation protocols that are mandatory and which employ non-quantitative criteria to exclude some projects as non-additional. ${ }^{65}$ For example, any projects receiving renewable energy credits under a separate regulatory scheme are disqualified.

Project proponents will submit applications to relevant authorities in each state and proponents of projects taking place outside the RGGI states will submit applications to any one of those regulators. The MOU says that "[a]t a minimum, eligible offsets shall consist of actions that are real, surplus, verifiable, permanent and enforceable." ${ }^{\text {"66 }}$ Project proponents must go through a two-step application process and projects must be verified after both steps by an accredited independent verifier. The first step is a "consistency determination," 67 whereby the applicable state regulatory agency would determine whether a project meets the eligibility criteria. At this stage, the regulatory agency has 90 days to determine whether the offset project is consistent with the offset project standard and if it is not, will inform the project sponsor of the project's deficiencies. ${ }^{68}$ In the second step, project proponents must submit annual monitoring and verification reports, which require the applicant to demonstrate the amount of GHG emissions reduced or sequestered before offset allowances are awarded. ${ }^{69}$

\section{Western Climate Initiative}

The Western Climate Initiative (WCI) was launched in February 2007 and includes Arizona, California, New Mexico, Oregon, Washington, Utah, British Columbia, Manitoba, Quebec, and Ontario. Alaska, Colorado, Idaho, Kansas, Nevada, Wyoming, Saskatchewan, and the Mexican states of Sonora, Baja California, Chihuahua, Coahuila, Nuevo Leon, and Tamaulipas have observer status. The WCI issued Design Recommendations for a Cap-and-

63 The initial list of project categories was selected with consideration of expected offset supply within the borders of MOU Signatory States, the relative ease of developing standards, and the likelihood of mandatory GHG regulations for that sector. Project types include: landfill methane capture and destruction reduction in emissions of sulfur hexafluoride $\left(\mathrm{SF}_{6}\right)$, sequestration of carbon due to afforestation reduction or avoidance of $\mathrm{CO}_{2}$ emissions from natural gas, oil, or propane, end use combustion due to ensure energy efficiency in the building sector, and avoided methane emissions from agricultural manure management operations. See ibid. RGGI, “Overview,” ibid.

Supra note 52, s. 10(5).

Supra note 50 at 4.

Supra note 52, s. 10.3(d)(1).

Ibid., s. 10.4(e)(2).

Ibid., s. 10.4 . 
Trade Program in September 2008. ${ }^{70}$ Both California ${ }^{71}$ and British Columbia ${ }^{72}$ have passed legislation that would allow them to implement cap-and-trade systems that would fall under the WCI plan.

\section{SCOPE AND TARGETS}

According to the Western Climate Initiative Statement of Regional Goal (the Statement), the WCI partners have agreed to meet a regional reduction goal of 15 percent below 2005 levels by 2020. ${ }^{73}$ According to the September 2008 Design Recommendations, the program will run from 2012 to 2020 in three-year compliance periods. In 2012, facilities that emit over 25 metric tonnes of GHGs per year will be capped. ${ }^{74}$ The WCI proposal includes electricity and industrial emissions, as well as transport, commercial, and residential emissions of all six GHGs. Transport, commercial, and residential emissions will be capped in the second phase of the program starting in 2015, including aviation. Emissions from these sources will be controlled by capping upstream entities like natural gas distribution companies and final blenders that bring transport and residential heating fuels into commerce in WCI. ${ }^{75}$

\section{ALLOCATIONS}

Under the Design Recommendations, participating states and provinces would have a GHG allowance budget to 2020 and would issue allowances to regulated entities in their respective jurisdictions. The Recommendations call on each partner to auction a minimum percentage of allowances - 10 percent in 2012 rising to 25 percent in $2020 .^{76}$

\section{PROJECT OFFSETS}

The WCI Design Recommendations call for the development of an initial set of eligible offset project types and approved protocols, a process to review and approve other project types and related protocols by project developers, a method that gives priority to offset projects located in the WCI and that ensures co-benefits, linking with other compliance emissions trading systems. Project types under "priority consideration" include: agriculture (soil sequestration and manure management); forestry (afforestation/reforestation, forest management, forest preservation/conservation forest products); and waste management (landfill gas and waste water management). ${ }^{77}$ The Design Recommendations propose to limit

Western Climate Initiative (WCI), Design Recommendations for the WCI Regional Cap-and-Trade Program (23 September 2008), online: WCI <http://www.westernclimateinitiative.org/ewebeditpro/ items/O104F20432.pdf $>$ [Design Recommendations].

71 U.S., A.B. 32, California Global Warming Solutions Act of 2006, 2005-06, Reg. Sess., Cal., 2006 (enacted) [A.B. 32].

72 38th Leg., British Columbia, 2008.

73 Western Climate Initiative, Western Climate Initiative Statement of Regional Goal (22 August 2007), online: WCI <http://www.westernclimateinitiative.org/ewebeditpro/items/O104F13006.pdf> at 3.

Ibid.

Ibid. at 1-2.

Ibid. at 6 .

Ibid. at 10 . 
the use of all offsets and allowances from other GHG emissions trading systems to 49 percent of total emissions reductions among all entities and facilities from 2012-2020. ${ }^{78}$ It is not yet clear how this goal will translate into regulatory obligations for capped emitters at the state or provincial level or what percentage of offsets will be allowed.

\section{MidWEStern Regional GreEnHouse Gas Reduction ACCORD}

In November 2007, Illinois, Iowa, Kansas, Michigan, Minnesota, Wisconsin, and Manitoba agreed under the Midwestern Greenhouse Gas Accord ${ }^{79}$ to develop a regional capand-trade system for GHGs by 2010. Ohio, Indiana, and South Dakota are observers. The Preamble of the MGA Accord notes specifically that the "U.S. federal government has not met the challenge to date of crafting a comprehensive national response to climate change, while governors representing U.S. states and national governments around the world have made commitments to reduce GHG emissions."80

The Preamble also emphasizes the economic benefits of regional co-operation in responding to a "carbon-constrained world" ${ }^{81}$ and points to:

[T]he region's comparative energy advantages, including:

1. ... energy efficiency programs; and

2. world-class renewable energy resources that support rapidly growing wind energy, corn ethanol and biodiesel industries, as well as the potential for robust cellulosic biomass and solar industries; and

3. extensive and secure coal reserves, combined with extensive geologic reservoirs for storing carbon dioxide $\left(\mathrm{CO}_{2}\right)$; and

4. pioneering experience with the capture of $\mathrm{CO}_{2} \ldots$; and

5. national leadership by the Midwest's agricultural and forestry communities to implement both methane mitigation and terrestrial carbon sequestration programs and practices. ${ }^{82}$

Parties to the MGA Accord agreed to complete a model rule for the implementation of the cap-and-trade system by November 2008. The MGA Accord says that the cap-and-trade program should: enable linkage to other jurisdictions' systems to create economies of scale; increase market efficiencies, diversity, and liquidity, while reducing costs; maximize economic and employment benefits, while minimizing any transitional job losses; reduce the shifting of generation and emissions to non-participating states; credit past and present

Ibid.

Midwestern Governors Association, Midwestern Greenhouse Gas Accord 2007, online: Midwestern Governors Association <http://www.midwesterngovernors.org/Publications/Greenhouse\%20gas\%20 accord_Layout\%201.pdf $>$ at 3 [MGA Accord].

Ibid.

Ibid. at 2 .

Ibid. 
actions to reduce GHG emissions; and address potential interaction or integration with a future federal program.

\section{GHG EMISSIONS TRADING IN CANADA}

\section{A. FEDERAL REgUlatory FrameWORK ON AIR EMISSIONS}

In April 2007, the Canadian government announced its Regulatory Framework on Air Emissions (the Framework) ${ }^{83}$ to control GHGs and air pollution, which is expected to come into force in 2010. The plan is the latest in a series of federal plans to regulate GHGs at the federal level in Canada.

\section{SCOPE AND TARGETS}

The Framework calls on the government to establish regulations that will require major industrial sectors to improve GHG emissions intensity by 18 percent by 2010 and an additional 2 percent per year to 2015 based on 2006 levels. According to the Framework, these targets will constitute a 150 megaton (MT) decrease in absolute GHG emissions by 2020 - a marked departure from Canada’s obligations under the Kyoto Protocol, which requires the country to effect a $220 \mathrm{MT}$ reduction from 2006 levels by $2012 .{ }^{84} \mathrm{New}$ facilities will be given a three-year grace period and certain industrial processes - called "[p]redefined fixed process emissions" will have a 0 percent reduction target for $2010 .^{85}$ The government is in the process of establishing sectoral targets for the six GHGs in major industrial sectors. ${ }^{86}$

\section{AlLOCATION}

As a baseline and credit system, there is no allocation of allowances in the Canadian program. However, under the Framework, the government will establish a baseline-intensity target for each firm and the firms whose actual emission intensity in a given year is below their target will receive tradable credits equal to the difference between their target and their actual emission intensity. Firms will be able to bank these credits and trade them with other regulated firms.

83 Environment Canada, Regulatory Framework for Air Emissions (Ottawa: Minister of Environment, 2007), online: ecoAction <http://www.ecoaction.gc.ca/news-nouvelles/pdf/20070426-1-eng.pdf> [EC, Framework].

84 Lisa (Elisabeth) DeMarco, Canada's Regulatory Framework on Air Emissions (27 April 2007), online: Macleod Dixon LLP <http://www.macleoddixon.com/documents/Canadas_Regulatory_Framework_ for_Air_Emissions.pdf $>$.

85 Supra note 83 at 11 . The Framework describes fixed process emissions as emissions that are tied to production and for which there is no alternative technology to reduce them. Examples cited by the Framework include: calcinations in cement and lime production (at 11).

86 Sectors include: electricity generation produced by combustion; oil and gas (including upstream oil and gas, downstream petroleum, oil sands, and natural gas pipelines); forest products (including pulp and paper and wood products); smelting and refining (including aluminum, alumina, and base metal smelting); iron and steel, potash, cement, lime, and chemicals production (including fertilizers). 


\section{PROJECT OFFSETS}

The Framework gives regulated emitters an unlimited right to use credits from offset projects in Canada in meeting intensity targets. As for offsets from outside Canada, the Framework indicates the government will allow Canadian firms to meet 10 percent of their compliance obligations using credits from the CDM. The Framework also adds that "the government will determine which types of Clean Development Mechanism credits should be eligible for regulatory compliance in Canada." ${ }^{87}$ The Framework says that Canada will work with the U.S. to explore opportunities for linking Canada's emissions trading system with regulatory-based emissions trading systems at the "regional and state level, and with any that may be established at the federal level" and that Canada will explore co-operation on emissions trading with Mexico. ${ }^{88}$

Details are still emerging on the federal offset system. In August 2008, the federal government published a draft protocol which provides guidelines for project protocol development as well as a framework for "fast track" approval of protocols and methodologies. ${ }^{89}$ During the first six months of the operation of the offset system, Environment Canada will implement a modified and accelerated process to review and approve “Offset System Quantification Protocols” that are derived from other systems, including: the Clean Development Mechanism, Alberta's offset system, the California Climate Action Registry, the Greenhouse Gas Abatement Scheme in New South Wales, France's offset system, and RGGI. ${ }^{90}$

\section{OTHER COMPLIANCE OPTIONS}

The Framework provides for a safety valve/cost ceiling by allowing emitters to contribute to a Technology Fund at a cost of CDN\$15 per ton to 2012 and \$20 per ton from 2012 to 2017, excluding adjustments for gross domestic product (GDP) growth. The maximum system-wide compliance obligation that can be met through fund purchases declines from 70 percent in 2010 to 10 percent in 2017 before it expires in 2018. The primary focus of the fund will be technology deployment and related infrastructure projects that have a high likelihood of yielding GHG emissions reductions. The Framework expressly contemplates funding carbon capture and sequestration and a $\mathrm{CO}_{2}$ pipeline in Alberta, as well as the development of an east-west electricity grid linking electricity markets from Manitoba to Newfoundland. An independent, not-for-profit entity administered by a board of directors composed of individuals originating from industry, federal, and provincial governments, and other stakeholders will be developed to administer the fund.

Supra note 83 at 15.

Ibid.

See Environment Canada, Turning the Corner: Canada's Offset System for Greenhouse Gases: Guide for Protocol Developers (August 2008) (Ottawa: Environment Canada, 2008), online: Environment Canada <http://www.ec.gc.ca/creditscompensatoires-offsets/7CAD67C6-B798-4B69-9648-BD7F1F74 B2CB/DRAFT\%20Guide_for_Protocol_Developers.pdf $>$. Under this proposed system the government would develop quantification protocols for landfill gas capture and destruction, reductions in methane from agriculture, soil management, afforestation, intermodal transportation, biofuels, geological sequestration, non-emitting energy, and energy efficiency. The project cycle would include four stages: registration, validation, verification, and issuance of credits (at 2).

Ibid. 


\section{B. Alberta's SPECIFIEd Gas EMitTERs REgulation}

In July 2007, Alberta became the first jurisdiction in North America to regulate GHGs. Alberta's Climate Change and Emissions Management Act ${ }^{91}$ was first introduced in 2002 with sections proclaimed in force in 2004, but the CCEMA, as a whole, was introduced under Bill 3 in March 2007 along with the accompanying Emitters Regulation, ${ }^{92}$ which came into force in July 2007. The CCEMA requires Alberta to reduce GHG emissions relative to GDP by 50 percent of 1990 levels by 2020 and the Emitters Regulation requires large emitters in the province to begin reducing emissions intensity immediately. In January 2008, the Alberta government announced a plan to reduce GHG emissions by 14 percent in absolute terms by $2050.9^{93}$

Alberta holds a unique position in Canada as the largest GHG emitter in the country, primarily due to its oil and gas production and heavy reliance on thermal power production. ${ }^{94}$ As such, the relatively early and proactive regulations in the province compared to other jurisdictions largely reflect Alberta's desire to manage GHG issues independently and its reluctance to participate in a federally designed GHG regulatory regime, which, up until 2006, endorsed Canada’s commitments under the Kyoto Protocol.

\section{SCOPE AND TARGETS}

The Emitters Regulation is a baseline and credit system like the Canadian federal system and unlike the American cap-and-trade systems under development. Sections 3 and 4 of the Emitters Regulation requires around 100 industrial facilities ${ }^{95}$ to reduce their GHG emissions intensity rates by 12 percent per year starting in 2007 and to submit yearly compliance reports to the Ministry of Environment. ${ }^{96}$ The targets in the Emitters Regulation are not absolute reductions but reductions per unit of economic output, so impose only a duty to improve efficiency rather than to reduce emissions. The Emitters Regulation gives the

\section{S.A. 2003, c. C-16.7 [CCEMA]. \\ Supra note 20.}

In January 2008, the Alberta government released its 2008 Climate Change Strategy (Strategy), which calls for a 14 percent reduction in GHG emissions from 2005 levels by 2050. The Strategy anticipates 12 percent of the reductions to come from conservation and efficiency improvements, 18 percent from renewable power generation, and 70 percent from carbon capture and storage technology. The Climate Change and Emissions Management Fund will be used in part to fund significant investments in carbon capture and storage. See Alberta Environment (AE), Alberta's 2008 Climate Change Strategy (January 2008), online: $\mathrm{AE}<\mathrm{http}: / /$ environment.alberta.ca/info/library/7894.pdf>.

In 2005, the largest provincial GHG emitters in Canada were Alberta (31 percent), Ontario (27 percent), Quebec (12 percent), Saskatchewan (10 percent), and British Columbia (9 percent). In that total emissions from Alberta were 233 MT and the largest sources in the province were mining, oil and gas (41 percent), and electricity and heat generation (23 percent). See Alberta Environment, Report on 2006 Greenhouse Gas Emissions, online: AE <http://environment.alberta.ca/documents/2006_GHG_ Report.pdf>.

The Emitters Regulation, supra note 20, applies to facilities in Alberta that had emissions totaling 100,000 tons or more in a year of commercial operation in any of the years between 2003 and 2006. Such facilities have been required to report GHG emissions since 2003 through the Alberta Specified Gas Reporting Regulation, Alta. Reg. 251/2004 and the national Greenhouse Gas Reporting program, online: Government of Canada <http://www.ghgreporting.gc.ca/GHGInfo/Pages/page2.aspx>. In 2006, there were 103 Alberta facilities that reported emissions totaling $115 \mathrm{MT}$. 
government powers to modify reduction targets over time and discretionary power to compel action where measures undertaken by regulated facilities are deemed inadequate for compliance. $^{97}$

\section{ALLOCATIONS}

As a baseline and credit system, there is no allocation of permits. The government requires each emitter to submit a current emissions intensity profile and improve intensity on an annual basis. Under s. 9 of the Emitters Regulation, a regulated facility that achieves an emissions intensity that is less than the applicable net emissions intensity limit for the period, has the right to apply for an "emission performance credit," which can be banked for future years or sold to another facility. Section 10(2) says "[n]othing in this Regulation ensures or guarantees the availability of ... credits,” and describes emissions performance credits as "revocable licences."98

\section{PROJECT OFFSETS}

The Emitters Regulation gives emitters an unlimited right to meet targets with offsets from Alberta. ${ }^{99}$ Section 7 says a project offset must: occur on or after 1 January 2002; be real, demonstrable, and quantifiable; not be required by law; have clearly established ownership; be counted only once for compliance purposes; be verified by a qualified third party; and have occurred in Alberta.

"Quantification Protocols"100 establish baseline calculation methods that are projection based and include dynamic modelling ${ }^{101}$ (except for afforestation projects, which only require static modelling ${ }^{102}$ and tillage projects, which call for a performance based approach ${ }^{103}$ ). On this basis, the Quantification Protocols appear to outline a fairly high standard for measuring

Ibid., s. 26, says the government can order the facility to obtain emission offsets or emission performance credits; make contributions to the Climate Management Fund; or "any other measures that the director considers advisable" (s. 26(2)(c)).

Supra note 20, s. 10.

Letter from Valerie Buhler to Grant Boyle (23 January 2008) [unpublished].

There are Quantification Protocols for afforestation, beef feeding, beef life cycle, biofuel, biogas, biomass, compost, energy efficiency, enhanced oil recovery, landfill gas, pork, tillage, and waste heat recovery.

Dynamic modelling assumes parameters like weather conditions, regulatory developments, market activity, project operations, and so forth may change during the credit period.

Static modelling assumes parameters like weather conditions, regulatory developments, market activity, project operations, and so forth do not change during the credit period.

A performance standard approach would use a typical emissions profile of an industry or sector as an approximation. 
reductions for the majority of project types. ${ }^{104}$ However, the Quantification Protocols are not mandatory and project developers are entitled to develop their own methods.

The Emitters Regulation does not require project developers to register the project with authorities or to have the project pre-validated by a third party. ${ }^{105}$ It appears as though government oversight occurs only once the project is completed and when the regulated emitter - having purchased credits privately, submits a "GHG Assertion" to the Ministry. The GHG Assertion is an application to the government for credit that is made in conjunction with the submission of a compliance report pursuant to ss. 3 and 4 . The government will not issue tradable credits to project developers per se. Instead, the government will review the GHG Assertions in conjunction with a particular emitter compliance report and decide at that stage whether to accept the offsets or not.

\section{OTHER COMPLIANCE OPTIONS}

Under the Emitters Regulation, facilities can also reach their targets by paying into a fund at a rate of CDN\$15 per ton of $\mathrm{CO}_{2}$ equivalent. Section 10 of the CCEMA established the Climate Change and Emissions Management Fund, ${ }^{106}$ administered by the Alberta Minister of Environment.

\section{Comparing Scope, Allocations, and Project Offsets}

Of all of the emissions systems discussed above, only Alberta has emissions trading laws that have come into force and many of the systems reviewed are at early stages of development and clearly subject to modification and further amendment. Nevertheless, some observations and comparisons can be made concerning the scope, allocation methods, and approaches to project offsets in each system.

The CSA represents a relatively ambitious and comprehensive blueprint to 2050 to address GHG reductions in the U.S. The CSA calls for an absolute target of 71 percent by 2050 for almost 90 percent of the American sources - a significant and comprehensive cap on its face in comparison to the medium-term plans of the Canadian federal government and the shorter term schemes under the RGGI and WCI.

According to a review written by Johanne Whitmore \& Nashina Shariff, the Quantification Protocols relating to power supply in the Alberta system provide an overly generous baseline scenario for clean energy project as the baseline is calculated on an average grid intensity. This baseline is seen as inappropriate since the new power supply is expected to be gas, which has lower unit emissions than what is reflected in the current grid intensity, where coal plays a significant role. See Johanne Whitmore \& Nashina Shariff, Comments on Alberta's Offset System Project Guidance Document (draft), dated 20 June 2007, online: The Pembina Institute <http://pubs.pembina.org/reports/Comments-Alb-offset.pdf> at 9 .

Alberta Environment, Offset Credit Project Guidance Document, online: AE <http://environment. alberta.ca/documents/Guidance_Document_Alberta_Offsets_v1.2_Feb_08.pdf $>$ [Project Guidance Document]. The Project Guidance Document does contemplate project validation by third party agents, if there is "demand." The Alberta government's stated position is that validation is essentially a business risk management service, which can be contracted to the private sector. The rationale for this approach was to provide a system, "without undue administrative burden for project developers" (at 7). Also, public registration of projects is not required, although "strongly encouraged." 
Unlike its counterparts in the U.S., the Canadian federal government does not have draft legislation for a multi-decade cap-and-trade system akin to the CSA. However, Canada has set short- and medium-term intensity targets that amount to a medium-term absolute reduction target of 20 percent to 2020 from 2006 levels for Canada's heavy industry — about 50 percent of the country's emissions. Both the Albertan and Canadian systems are based on intensity targets, so offer no assurance that absolute reductions will occur. In the case of Alberta, given projected economic growth rates, absolute emissions are likely to rise considerably under the current intensity cap in the Emitters Regulation. ${ }^{107}$ The RGGI, WCI, and the MGA Accord plans establish absolute caps on emissions in their proposed trading programs.

The CSA, RGGI, and WCI appear to favour auctions over grandfathering. Both the Albertan and Canadian systems are baseline and credit systems which do not allocate allowances but designate baseline emissions levels for a given emitter.

The RGGI and CSA also make use of so-called "set-asides" — that is, the government will give away allowances as subsidies to uncapped emitters such as renewable energy operators or low-income electricity consumers. On its face, this approach appears as an innovative attempt to address the potential, regressive effects of climate policies on low-income Americans and to help promote technical innovation in addition to capping polluters. Although the Albertan and Canadian systems do not contemplate set-asides, they do establish a technology fund to support technology development.

The American schemes limit the number of offset credits that capped emitters can use to meet their compliance obligations. Power facilities under the RGGI are allowed to meet 3.3 percent of their cap through offsets, although this portion can rise to 10 percent if the price of allowances exceeds a certain threshold. Thus, there is greater access to offsets if internal abatement is too expensive as expressed in the price of allowances. Emitters under the CSA would have a right to meet 30 percent of their cap through offsets, 15 percent from offsets in the U.S., and 15 percent from international offsets. By contrast, both the Albertan and Canadian systems establish emitter rights that allow unlimited use of offsets, 10 percent of which can come from the CDM in the Canadian system.

Both the RGGI and CSA appear to rely on predetermined protocols for calculating offset project reductions. By establishing protocols, the RGGI and CSA systems may encourage standardization, which will likely enhance the rigour of regulatory assessment of projects and help to lower transaction costs. Certification rules in the Albertan offset system also have pre-defined protocols for calculating offset reductions, but project developers are not required to use these protocols. There are also no registration or pre-government oversight requirements for Albertan projects, unlike the draft rules in other regimes.

In sum, there are different types of GHG emissions trading systems emerging in North America with significantly different design features. Generally, American plans at the federal level, although at an earlier stage of development than the Canadian plans, are more stringent and comprehensive than the Canadian plans as reflected in the scope, targets, methods of 
allocation, and availability of offsets. Considering the two most highly developed sub-federal level initiatives - Alberta's Emitters Regulation and the RGGI — the same finding holds true. The RGGI has an absolute cap, auctions allowances, and allows only limited use of offsets, whereas Alberta imposes an intensity cap (although on a larger cross section of industry than the RGGI), grandfathers emissions rights through a baseline and credit system, allows unlimited use of offsets, and allows for emitters to pay into a technology fund for compliance that caps prices at CDN\$15 per ton.

\section{IMPLICATIONS AND DISCUSSION}

\section{A. Fragmentation Before ConVERgence in North AMERicA?}

Judging simply by the number of different programs, it would appear that North American emissions trading is headed toward a patchwork of systems quite unlike the EU-ETS or the global emissions trading contemplated by the Kyoto Protocol. The provincial and state level trading schemes canvassed above are discrete regulatory projects with different goals and characteristics. The RGGI is a short-term experiment among a small group of neighbouring states that share power supply infrastructures. The MGA Accord is centred on jobs and economic opportunities associated with sequestering carbon from coal and adapting its agriculture sector to biofuels. Alberta's Emitters Regulation appears to be an attempt to stave off potentially more onerous federal regulations than the province is willing to impose, or at least stake out a negotiating position with the federal government.

American state systems may converge under a bill like the CSA in coming years. The RGGI's MOU specifically contemplates working within a federal cap-and-trade scheme once implemented ${ }^{108}$ and the MGA Accord contemplates "potential interaction or integration with a future federal program." ${ }^{109}$ Also, the Canadian federal program discusses "equivalency agreements," prevail over federal ones. Also, it is important to keep in mind that the development of state, provincial, and regional systems has taken place in the absence of strong leadership from both American and Canadian federal governments on the climate change issue. The two current American Presidential nominees have stated that they would establish a national capand-trade program for GHG emissions, although such a plan would still require congressional approval. Once there is more decisive action from a new American administration, the Canadian federal government may also follow suit in creating a system that mirrors something like the CSA.

However, based on activity to date, there will likely be more fragmentation before there is any convergence in North American GHG emissions trading, and even if systems do converge in the future, these federal systems will likely need to accommodate significant differences. On one hand, there are groups that want to move further and faster. California - through the WCI, unlike the RGGI or the MGA Accord - has a clear streak of independence. The preamble of A.B. 32 envisions California leadership on climate change 
to have far-reaching effects on other states, the federal government, and other countries, and highlights California as a leader in environmental regulation and the potential economic benefits of promoting "pioneering technologies." 111

Indeed, the WCI is already engaged in international co-operation among western states and western provinces as well as making efforts at linking to the EU-ETS though the International Carbon Action Partnership. ${ }^{112}$ This approach is in keeping with California's leadership on environmental regulation in general in the U.S. Surely, the Californian approach will continue to diverge from that of other states - not only those who have put forward their own approaches to GHG emissions trading such as the RGGI or the MGA Accord, but also those who have not yet joined any GHG emissions trading schemes.

Alberta stands out as an exception in the Canadian context, but quite unlike California, has staked out a less onerous regulatory trajectory than what the Canadian federal government has contemplated. In fact, the preamble of Alberta's legislation suggests that Alberta's plan does not accept the constitutional authority of the Canadian federal government to regulate GHG emissions in Alberta. ${ }^{113}$ The approach in Alberta contrasts with other provincial efforts underway. Hydro power-rich British Columbia and Manitoba, for example, have joined California in the WCI. British Columbia has recently introduced a carbon tax and a province-wide cap-and-trade law and has committed to reduce GHG emissions by 33 percent by 2020 from 2007 levels. Thus, Alberta and British Columbia, Canada's two most western provinces, have both moved briskly ahead of the federal government on climate change policy, but in quite different directions.

\section{B. INTERNATIONAL GHG EMISSIONS TRADING}

The bottom up approach to policy development seen to date in North American GHG emissions trading could be emblematic of policy development processes in the U.S. and Canada, particularly during a time of conservative federal leadership. Even if we tentatively conclude that North American emissions trading will converge into a more centralized system in coming years, it is clear that North American emissions trading is being

Supra note 71, s. 38501(e). A.B. 32 in ss. 38501(c)-(d) reads:

California has long been a national and international leader on energy conservation and environmental stewardship efforts, including the areas of air quality protections, energy efficiency requirements, renewable energy standards, natural resource conservation, and greenhouse gas emission standards for passenger vehicles. The program established by this division will continue this tradition of environmental leadership by placing California at the forefront of national and international efforts to reduce emissions of greenhouse gases. National and international actions are necessary to fully address the issue of global warming. However, action taken by California to reduce emissions of greenhouse gases will have far-reaching effects by encouraging other states, the federal government, and other countries to act.

See online: International Carbon Action Partnership <http://www.icapcarbonaction.com>.

The preamble of the CCEMA, emphasizes Alberta's ownership over its natural resources and declares GHGs - carbon dioxide and methane - to be "non toxic," thus (in the view of the Act), asserting provincial authority over GHGs vis-à-vis the federal government. The federal government plans to regulate GHGs under the Canadian Environmental Protection Act, S.C. 1999, c. 33, which is authorized to regulate toxins. See Alastair R. Lucas, "Canada's Role in The United States' Oil and Gas Supply Security: Oil Sands, Arctic Gas, NAFTA, and Canadian Kyoto Protocol Impacts” (2004) 25 Energy L.J. 403. 
constructed quite differently than the EU-ETS and certainly unlike the global emissions trading envisioned under the Kyoto Protocol. Indeed, in light of the diverse versions of emissions trading canvassed above, the globally harmonized GHG emissions trading of the Kyoto Protocol looks extraordinarily ambitious.

This is not to say that integrated international emissions trading will never happen or that some form of it could not be helpful in promoting co-operation and cost-effective GHG reductions. However, the GHG emissions trading systems that are emerging appear to be taking place among political economic units with similar political values, economic geographies, and institutions. The EU-ETS may prove to be an exception in terms of its international scope and centralized approach, as the European Commission has regulatory powers unlike other international institutions. Even then, the EU-ETS, while receiving strong guidance from the European Commission, is still comprised of a collective set of diverse approaches to caps, allocation plans, and so forth. ${ }^{114}$ David G. Victor argues that "zones" of capable countries are likely to develop meaningful emissions markets before an international body like the United Nations does. ${ }^{115}$ He suggests that such zones will share intense trading and investment relationships with each other, and importantly, have institutions that recognize one another and have confidence in the institutional capabilities of their partner states: "Carbon markets are likely to be fragmented rather than integrated - a world that is second best in theory but first best when the theories are updated to reflect how property rights can be assigned, monitored and enforced."

Decentralization also allows different jurisdictions to develop GHG emissions trading schemes that incorporate policy goals that may be region-specific and these will almost certainly include policy goals beyond global costs effectiveness. The best technology options for GHG reductions, for example, may be unique to a given location or region. ${ }^{117}$ Alberta, for example, has allowed emitters to pay into a technology fund at a rate of CDN\$15 per ton as a form of compliance in its emissions trading scheme. From the perspective of emissions trading theory, this price cap appears economically inefficient, but seen in another light, the technology fund is a means to centrally finance carbon capture and storage, which the province has designated as a key technology to reduce emissions from coal power and oil sands development. The federal fund appears to be similarly aimed at carbon capture and storage as well as power grid expansion between Canadian provinces. The MGA Accord specifically mentions biofuels and carbon capture in its preamble; solutions that are squarely aligned with the economic geography of that region. British Columbia is promoting the use of forestry-based sequestration approaches in the WCI owing to its forest resources and skills. The province is more likely to achieve such provisions in the WCI than it would under CDM negotiation at the UNFCCC, which has been reluctant to allow forestry related offsets,

David G. Victor, "Fragmented carbon markets and reluctant nations: implications for the design of effective architectures" in Joseph E. Aldy \& Robert N. Stavins, eds., Architectures for Agreement: Addressing Global Climate Change in the Post-Kyoto World (Cambridge, U.K.: Cambridge University Press, 2007) 133 at 144.

$116 \quad$ Ibid. at 134-35.

117 Potential GHG mitigation opportunities and challenges are significantly diverse, as well as dispersed across economic geographies. This situation may be quite different from other global pollution problems like ozone depletion, which have more standard solutions available. 
partly out of concern for flooding the global market with cheap credits, but also because forestry projects are controversial in the Kyoto Protocol in light of developing country expectations for technology transfer and the equity concerns related to the appropriation of land in developing countries for forest preservation.

The Kyoto Protocol's inability to elicit greater participation has led some to call into question the efficacy of the "mega-multilateral" approach of international environmental law in general. ${ }^{118}$ Certainly, this article has revealed a fragmented regionalism in the North American GHG emissions trading plans. However, the framework approach of international environmental law has long recognized the need for flexible solutions to allow for changing scientific evidence, new control technologies, new political priorities, and the differing circumstances of various states. ${ }^{119}$ What could be described as the shortcomings of the Kyoto Protocol - insufficient targets and lack of universal participation - could also be described as the framework approach functioning to accommodate difference. Ultimately, the harmonizing function of international environmental agreements serves an important purpose in overcoming the competitiveness concerns that arise from unilateral national regulation and in forging coordinated responses to global problems. The continued negotiation of country reduction targets, as under art. 3.1 of the Kyoto Protocol, is surely an important step in global climate change mitigation efforts, and countries and regions should be accountable on the world stage for their efforts.

However, the Kyoto Protocol's attempt to harmonize emissions trading takes regulatory harmonization to a new level in international environmental treaty-making. Articles 6, 12, and 17, while innovative, may substitute the legal logic of harmonized state regulation for the economic logic associated with the harmonization of markets. Whether intended or not, emissions trading under the Kyoto Protocol mirrors processes of standardization and harmonization that underpin the globalization of capital and finance. Yet, at the same time, the harmonization of GHG commodification rules remains seriously incomplete under the Kyoto Protocol and politically problematic in many domestic instances. In emissions trading language, art. 3.1 acts effectively as a global cap on GHG emissions, but three of the world's largest emitters, the U.S., China, and India are not included and emissions allowances were effectively allocated through diplomatic negotiations that were out of touch with the economic realities of mitigation opportunities and costs.

Allowance trading under art. 17, although not underway in any meaningful way, has been unable to shake its reputation as the trade in "hot air" from the post-Soviet bloc despite efforts to "green" these allowances by aligning them with emissions reduction projects in host countries. The CDM is probably the most successful emissions trading device under the Kyoto Protocol and will likely endure as a code for international carbon finance, but it remains controversial. This is partly because of the general challenge of any offset program, as discussed in Part II.B, but also because the CDM has such diverse stakeholders with diverse expectations: project developers, bankers, international development interests,

118 Mathew Hoffman, “The Global Regime: Current Status of and Quo Vadis for Kyoto,” in Steven Berstein et al., eds., A Globally Integrated Climate Policy for Canada (Toronto: University of Toronto Press, 2008) 137 at 151.

119 Patricia W. Birnie \& Alan E. Boyle, International Law \& the Environment, 2d ed. (Oxford: Oxford University Press, 2002) at 8. 
UNFCCC negotiators, and so on. Various policy experts and commentators in Canada are generally distrustful of the CDM due to its apparent inefficacy in reducing Canadian emissions, ${ }^{120}$ even if those commentators misapprehend the political salience of the CDM under the UNFCCC and the important role of technology transfer in the international environmental treaty negotiations in which Canada partakes.

Perhaps some of these flexible mechanisms will disappear from the North American mix of emissions trading instruments in a post-2012 climate agreement and international emissions trading will remain a regional affair rather than a global one. Indeed, the CSA discussed above contemplates the use of trade restrictions if other countries do not cap GHG emissions in a similar manner to the CSA. Title VI of the Bill would authorize the President to require importers of greenhouse-gas-intensive manufactured products (steel, aluminum, and so forth) to submit emission credits of a value equivalent to the credits that the American system effectively requires of domestic manufacturers if it is found that a given major emitting country has not taken "comparable action" to the U.S. after eight years of the enactment of the U.S. program. ${ }^{121}$ Whether or not such a policy would pass international trade law requirements is a different question. However, the draft language of the provisions indicates the Bill has been crafted to meet the environmental exemptions under the World Trade Organization. ${ }^{122}$ If so, perhaps the CSA resembles an approach to emissions trading harmonization that is leveraged in the rules of international trade rather than an international environmental treaty. ${ }^{123}$ In any case, international co-operation on GHG emissions trading is likely to emerge through incremental experimentation rather than a global design.

\section{CONCLUSION}

This snapshot of GHG emissions trading in North America shows a diverse patchwork of regulatory systems. It is difficult to gauge whether or not this diversity will persist in coming years, as the political and scientific context surrounding climate change is moving quickly. Nevertheless, this divergence is still revealing in various respects. For one, the clear divergence in scope, allocations methods, and project offset treatment among the systems canvassed above illustrate how diverse emissions trading systems, in fact, can be. This calls into question both the praise and the criticisms that are levelled at emissions trading in general. The design features above show that the market efficacy, environmental stringency,

Jeffrey Simpson, Mark Jaccard \& Nic Rivers, Hot Air: Meeting Canada's Climate Change Challenge (Toronto: McClelland \& Stewart, 2007) at 248.

$121 \quad$ Supra note 33, s. 6601(2).

122 In the Shrimp-Turtle case, the WTO Appellant Body upheld a U.S. import restriction on shrimp where the exporting country did not have environmental standards "comparable in effectiveness" to the U.S. regulation, thus allowing extrajurisdictional regulations to apply under art. 20 of the General Agreement on Tariffs and Trade. See WTO, United States - Import Prohibition of Certain Shrimp and Shrimp Products: Recourse to Article 21.5 of the DSU by Malaysia (Report of the Appellate Body) (21 October 2001), WTO Doc. WT/DS58/AB/RW, online: WTO <http://www.wto.org/english/tratop_e/dispu_e/ 58abrw_e.pdf> at para. 144. Notably, the draft CSA, supra note 33, defines “Comparable Action” under Title VI [emphasis added] as: "any greenhouse gas regulatory programs, requirements, and other measures adopted by a foreign country that, in combination, are comparable in effect to actions carried out by the United States to limit greenhouse gas emissions pursuant to this Act ... taking into consideration the level of economic development of the foreign country."

123 See Oren Perez, "International Trade Law and the Environment" in Richardson \& Wood, supra note 8, 381. 
and social fairness of an emissions trading system will depend on how that system is designed. This finding, in turn, points to the role governments have - rather than carbon markets per se - to ensure the quality of emissions trading systems and climate change mitigation efforts in general.

This divergence also highlights the problematic nature of global GHG emissions trading under the Kyoto Protocol. In reflecting upon the disparate values, incentives, and circumstances that inform the creation of emissions trading systems in North America even between groups as institutionally competent, culturally similar, and proximate as British Columbians and Albertans - the prospect of global emissions trading, as envisioned under the Kyoto Protocol, appears more as a beacon in the distance, rather than as a practicable trial run or foundational architecture. The pattern observed in this article suggests that international emissions trading will only be built up incrementally, if at all, even if in theory a global carbon price is desirable from the outset. This does not mean that climate change does not require a harmonized global response in international law. Collective efforts and assurances are required. But it does question the efficacy of further efforts to establish comprehensive global emissions trading in a centralized manner as well as efforts to achieve a single global carbon market even through a stepwise approach. GHG cap-and-trade systems are likely best viewed as promising domestic or regional instruments among a range of required regulatory instruments and voluntary initiatives rather than as the basis for international co-operation. 
VIII. APPENDiX A:

Proposed Emissions Allowances Allocation ${ }^{124}$

\begin{tabular}{|c|c|c|c|c|c|}
\hline \multicolumn{2}{|c|}{$\begin{array}{c}2012 \text { Emission Allowance } \\
\text { Account }\end{array}$} & \multicolumn{2}{|c|}{$\begin{array}{c}2022 \text { Emission Allowance } \\
\text { Account }\end{array}$} & \multicolumn{2}{|c|}{$\begin{array}{c}2031 \text { Emission Allowance } \\
\text { Account }\end{array}$} \\
\hline Recipient & $\%$ & Recipient & $\%$ & Recipient & $\%$ \\
\hline \multicolumn{6}{|c|}{ Transition Assistance } \\
\hline $\begin{array}{r}\text { Fossil Fuel-Fired Power } \\
\text { Plants }\end{array}$ & 19 & $\begin{array}{r}\text { Fossil Fuel-Fired Power } \\
\text { Plants }\end{array}$ & 13 & $\begin{array}{r}\text { Fossil Fuel-Fired Power } \\
\text { Plants }\end{array}$ & 0 \\
\hline $\begin{array}{r}\text { Energy Intensive } \\
\text { Manufacturing } \\
\end{array}$ & 10 & $\begin{array}{r}\text { Energy Intensive } \\
\text { Manufacturing } \\
\end{array}$ & 7 & $\begin{array}{r}\text { Energy Intensive } \\
\text { Manufacturing } \\
\end{array}$ & 0 \\
\hline $\begin{array}{r}\text { Companies That Took } \\
\text { Early Action }\end{array}$ & 5 & $\begin{array}{r}\text { Companies That Took } \\
\text { Early Action }\end{array}$ & 0 & $\begin{array}{r}\text { Companies That Took } \\
\text { Early Action }\end{array}$ & 0 \\
\hline $\begin{array}{r}\mathrm{CO}_{2} \text { Sequestration } \\
\text { Bonus Account } \\
\end{array}$ & 4 & $\begin{array}{r}\mathrm{CO}_{2} \text { Sequestration } \\
\text { Bonus Account } \\
\end{array}$ & 4 & $\begin{array}{r}\mathrm{CO}_{2} \text { Sequestration } \\
\text { Bonus Account }\end{array}$ & 0 \\
\hline $\begin{array}{r}\text { Petroleum Importers } \\
\text { and Refiners }\end{array}$ & 2 & $\begin{array}{r}\text { Petroleum Importers and } \\
\text { Refiners }\end{array}$ & 1.75 & $\begin{array}{r}\text { Petroleum Importers and } \\
\text { Refiners }\end{array}$ & 0 \\
\hline $\begin{array}{r}\text { HFC Producers and } \\
\text { Importers } \\
\end{array}$ & 2 & $\begin{array}{r}\text { HFC Producers and } \\
\text { Importers } \\
\end{array}$ & 1.75 & $\begin{array}{r}\text { HFC Producers and } \\
\text { Importers } \\
\end{array}$ & 0 \\
\hline $\begin{array}{r}\text { Rural Electric } \\
\text { Cooperatives } \\
\end{array}$ & 1 & $\begin{array}{r}\text { Rural Electric } \\
\text { Cooperatives } \\
\end{array}$ & 1 & $\begin{array}{r}\text { Rural Electric } \\
\text { Cooperatives } \\
\end{array}$ & 0 \\
\hline TOTAL & 43 & TOTAL & 28.5 & TOTAL & 0 \\
\hline \multicolumn{6}{|c|}{ Entities Other Than Regulated Emitters } \\
\hline $\begin{array}{r}\text { Annual Auction and } \\
\text { Early Action }\end{array}$ & 26.5 & $\begin{array}{r}\text { Annual Auction and } \\
\text { Early Action }\end{array}$ & 41 & $\begin{array}{r}\text { Annual Auction and } \\
\text { Early Action }\end{array}$ & 69.5 \\
\hline States & 10.5 & States & 10.5 & States & 10.5 \\
\hline Electricity Consumers & 9 & Electricity Consumers & 9 & Electricity Consumers & 9 \\
\hline $\begin{array}{r}\text { U.S. Farmers and } \\
\text { Foresters }\end{array}$ & 5 & $\begin{array}{r}\text { U.S. Farmers and } \\
\text { Foresters }\end{array}$ & 5 & $\begin{array}{r}\text { U.S. Farmers and } \\
\text { Foresters }\end{array}$ & 5 \\
\hline $\begin{array}{r}\text { International Forest } \\
\text { Protection } \\
\end{array}$ & 2.5 & $\begin{array}{r}\text { International Forest } \\
\text { Protection } \\
\end{array}$ & 2.5 & $\begin{array}{r}\text { International Forest } \\
\text { Protection } \\
\end{array}$ & 2.5 \\
\hline Natural Gas Consumers & 2 & Natural Gas Consumers & 2 & Natural Gas Consumers & 2 \\
\hline $\begin{array}{r}\text { Reducing Coal Mine, } \\
\text { Landfill Methane }\end{array}$ & 1 & $\begin{array}{r}\text { Reducing Coal Mine, } \\
\text { Landfill Methane }\end{array}$ & 1 & $\begin{array}{r}\text { Reducing Coal Mine, } \\
\text { Landfill Methane }\end{array}$ & 1 \\
\hline Tribal Governments & 0.5 & Tribal Governments & 0.5 & Tribal Governments & 0.5 \\
\hline TOTAL & 57 & TOTAL & 71.5 & TOTAL & 100 \\
\hline
\end{tabular}




\begin{tabular}{|c|c|c|c|c|c|c|c|c|}
\hline \multicolumn{3}{|c|}{$\begin{array}{c}2012 \text { Emission Allowance } \\
\text { Account } \\
\end{array}$} & \multicolumn{3}{|c|}{$\begin{array}{c}2022 \text { Emission Allowance } \\
\text { Account } \\
\end{array}$} & \multicolumn{3}{|c|}{$\begin{array}{c}2031 \text { Emission Allowance } \\
\text { Account }\end{array}$} \\
\hline $\begin{array}{l}\text { Use of Auction } \\
\text { Proceeds }\end{array}$ & $\%$ & & $\begin{array}{l}\text { Use of Auction } \\
\text { Proceeds }\end{array}$ & $\%$ & & $\begin{array}{l}\text { Use of Action } \\
\text { Proceeds }\end{array}$ & $\%$ & \\
\hline $\begin{array}{l}\text { Technology } \\
\text { Deployment }\end{array}$ & 52 & & $\begin{array}{l}\text { Technology } \\
\text { Deployment }\end{array}$ & 52 & & $\begin{array}{l}\text { Technology } \\
\text { Deployment }\end{array}$ & 52 & \\
\hline $\begin{array}{r}\text { Low-Income } \\
\text { Energy } \\
\text { Consumers }\end{array}$ & 18 & & $\begin{array}{r}\text { Low-Income } \\
\text { Energy } \\
\text { Consumers }\end{array}$ & 18 & & $\begin{array}{r}\text { Low-Income } \\
\text { Energy } \\
\text { Consumers }\end{array}$ & 18 & \\
\hline $\begin{array}{r}\text { Wildlife } \\
\text { Adaptation }\end{array}$ & 18 & & $\begin{array}{r}\text { Wildlife } \\
\text { Adaptation }\end{array}$ & 18 & & $\begin{array}{r}\text { Wildlife } \\
\text { Adaptation }\end{array}$ & 18 & \\
\hline $\begin{array}{r}\text { International } \\
\text { Adaptation }\end{array}$ & 5 & & $\begin{array}{r}\text { International } \\
\text { Adaptation }\end{array}$ & 5 & & $\begin{array}{r}\text { International } \\
\text { Adaptation }\end{array}$ & 5 & \\
\hline $\begin{array}{l}\text { Worker } \\
\text { Training }\end{array}$ & 5 & & Worker Training & 5 & & Worker Training & 5 & \\
\hline $\begin{array}{r}\text { Advanced } \\
\text { Energy } \\
\text { Research } \\
\end{array}$ & 2 & & $\begin{array}{r}\text { Advanced } \\
\text { Energy Research }\end{array}$ & 2 & & $\begin{array}{r}\text { Advanced } \\
\text { Energy } \\
\text { Research }\end{array}$ & 2 & \\
\hline TOTAL & 100 & & TOTAL & 100 & & TOTAL & 100 & \\
\hline \multicolumn{2}{|c|}{ TOTAL } & 100 & \multicolumn{2}{|c|}{$\overline{\text { TOTAL }}$} & 100 & \multicolumn{2}{|c|}{ TOTAL } & 100 \\
\hline
\end{tabular}

